1 Influence of Photochemical Loss of VOCs on Understanding Ozone \title{
Formation Mechanism
}

3 Wei Ma ${ }^{1}$, Zemin Feng ${ }^{1}$, Junlei Zhan ${ }^{1}$, Yongchun Liu ${ }^{1 *}$, Pengfei Liu ${ }^{2,4,5}$, Chengtang Liü ${ }^{2,4,5}$, Qingxin Ma ${ }^{2,4,5}$,

5 1. Aerosol and Haze Laboratory, Advanced Innovation Center for Soft Matter Science and Engineering,

6 Beijing University of Chemical Technology, Beijing, 100029, China

7 2. Research Center for Eco-Environmental Sciences, Chinese Academy of Sciences, Beijing, 100085, China

8 3. Beijing Institute of Petrochemical Technology, Beijing 102617, China

9 4. Center for Excellence in Regional Atmospheric Environment, Institute of Urban Environment, Chinese

10 Academy of Sciences, Xiamen 361021, China

11 5. University of Chinese Academy of Sciences, Beijing 100049, China

12 6. Institute for Atmospheric and Earth System Research, Faculty of Science, University of Helsinki, Helsinki,

13 00014, Finland

14 *Corresponding to: Yongchun liu (liuyc@buct.edu.cn) and Junfeng Liu (junfengliu@rcees.ac.cn)

15 


\section{Abstract}

Volatile organic compounds (VOCs) tend to be consumed by atmospheric oxidants,

resulting in substantial photochemical loss during transport. An observation-based model is

19 used to evaluate the influence of photochemical loss of VOCs on the sensitivity regime and mechanisms of ozone formation. Our results showed that a VOC-limited regime based on the observed VOC concentrations shifted to a transition regime with the photochemical initial concentration of VOCs (PIC-VOCs) in the morning. The net ozone formation rate was

23 underestimated by $3 \mathrm{pp} \mathrm{h}^{-1}\left(36 \mathrm{ppb}^{-1} \mathrm{yy}^{-1}\right)$ based on the PIC-VOCs. The relative contribution

24 of the $\mathrm{RO}_{2}$ path to ozone production based on the PIC-VOCs accordingly increased by $13.4 \%$,

25 particularly, the contribution of alkenes derived $\mathrm{RO}_{2}$ increased around $10.2 \%$. The contribution

26 of local photochemistry might be underestimated to both local and regional ozone pollution if the consumed VOCs was not accounted for, and policy-making on ozone pollution prevention should focus on high-reactivity VOCs. 


\section{Introduction}

Ground surface ozone $\left(\mathrm{O}_{3}\right)$ is an important atmospheric pollutant that is harmful to human

(Cohen et al., 2017). It is also harmful to vegetation growth. For example, it led to annual reduction of the yield of rice and wheat by $8 \%$ and $6 \%$, respectively, and the forest biomass growth by $11-13 \%$ in China (Feng et al., 2019). Surface $\mathrm{O}_{3}$ concentrations have increased by $11.9 \%$ over eastern China under the air pollution control measures implemented in China from 2012 to 2017 (Dang and Liao, 2019). An economic loss will be 0.09\% of the Chinese gross domestic products ( 78 billion $\mathrm{CNY}$ ) in 2030 if the policies against $\mathrm{O}_{3}$ pollution are not properly implemented (Xie et al., 2019). Therefore, it is urgent to take actions on $\mathrm{O}_{3}$ pollution in China. organic compounds (VOCs) and nitrogen oxides ( $\mathrm{NO} x$ : $\mathrm{NO}+\mathrm{NO}_{2}$ ) (Seinfeld and Johnh, 2006; Zhang et al., 2021c). $\mathrm{O}_{3}$ is generated from the collision of $\mathrm{O}_{2}$ and $\mathrm{O}(3 \mathrm{P})$ that are produced from

43 the photolysis of $\mathrm{NO}_{2}$ in the atmosphere. Peroxyl radicals $\left(\mathrm{HO}_{2}\right.$ and $\left.\mathrm{RO}_{2}\right)$, which produced

44 from oxidation of VOCs by OH radical, can efficiently convert NO (from the photolysis of $45 \mathrm{NO}_{2}$ ) to $\mathrm{NO}_{2}$, then lead to net $\mathrm{O}_{3}$ production by compensating the titration of $\mathrm{O}_{3}$ by $\mathrm{NO}$ (Monks, 2005; Zhang et al., 2021a). Over past two decades, a number of field observations focused on

47 the pollution level of $\mathrm{O}_{3}$ and its precursors have been carried out in Beijing-Tianjin-Hebei 48 (BTH), the Yangtze River Delta (YRD), and Pearl River Delt (PRD) regions (Wang et al., 2017;

49 Li et al., 2019; Xue et al., 2014; Zhang et al., 2019). Due to the nonlinear relationship between

$50 \mathrm{O}_{3}$ and its precursors and the variations of meteorological conditions, numerous studies have 
51 been performed for understanding the sensitivity regime (Ling and Guo, 2014; Zhang et al.,

522020 ) and the photochemical process of $\mathrm{O}_{3}$ formation based on box model or observation-based

53 model (OBM) (He et al., 2019; Tan et al., 2019), and the source-receptor relationship of $\mathrm{O}_{3}$

54 using a regional chemical transport mode ( $\mathrm{Li}$ et al., 2016b; Li et al., 2016c). Recently, $\mathrm{O}_{3}$

55 formation process, from the perspective of the instantaneous production rate, has attracted more

56 attention, such as the radical recycle $\left(\mathrm{OH}-\mathrm{RO}_{2}-\mathrm{RO}-\mathrm{HO}_{2}-\mathrm{OH}\right)$ relating to production of $\mathrm{O}_{3}(\mathrm{Lu}$

57 et al., 2017; Tan et al., 2017; Whalley et al., 2018). It has been found that HCHO photolysis

58 and alkene ozonolysis contributed about $85 \%$ of the primary production of $\mathrm{HO}_{2}$ and $\mathrm{HO}$

59 radicals in Beijing, Shanghai and Guangzhou (Tan et al., 2019; Yang et al., 2017). The

60 importance of $\mathrm{HONO}$ and $\mathrm{HCHO}$ photolysis for primary radical production has also been

61 proposed in suburban and rural areas (Tan et al., 2017; Lu et al., 2012; Lu et al., 2013).

It should be pointed out that all of the OBM studies were based on the measured dataset

65 lifetimes of some highly reactive VOCs such as isoprene are only as short as several ten minutes under the typical daytime atmospheric conditions. Thus, the mixing ratio of VOCs observed at

67 a sampling site may differ from that at the source regions because of the photochemical loss

68 even during a short-range of transport. This may mislead the $\mathrm{O}_{3}$ formation sensitivity, net $\mathrm{O}_{3}$

69 production, subsequently, the policy-making on $\mathrm{O}_{3}$ pollution prevention. Thus, the

70 photochemical-age-based approach has been applied to evaluate the effect of photochemical

71 process on VOC measurements (Shao et al., 2011). This method was used to qualitatively or 
72 semi-quantitatively estimate the $\mathrm{O}_{3}$ formation process of the source-receptor (Gao et al., 2018),

73 such as calculating $\mathrm{O}_{3}$ formation potential (OFP) (Han et al., 2017), identifying the critical

74 species for $\mathrm{O}_{3}$ formation (Gao et al., 2021), and evaluating the VOCs emission ratio (Yuan et

75 al., 2013). However, it is unclear how the highly reactive VOCs, which has degraded during transport from the source to the receptor site, will affect the instantaneous formation process of $\mathrm{O}_{3}$. Beijing based on the concentrations of the observed and photochemical initial concentrations of VOCs (PIC-VOCs). The $\mathrm{O}_{3}-\mathrm{NO} x$-VOCs sensitivity, the instantaneous $\mathrm{O}_{3}$ formation rate and the in-situ $\mathrm{O}_{3}$ formation process are discussed. The aim of this study is to understand the

82 possible influence of photochemical loss of VOCs on the diagnosis of the formation sensitivity regime of $\mathrm{O}_{3}$. This study can provide a new insight for better understanding atmospheric $\mathrm{O}_{3}$ pollution.

\section{2. Methodology}

\section{$86 \quad 2.1$ Experimental section}

Field observations were carried out in the Qingyuan campus of Beijing Institute of Petrochemical Technology (BIPT, $39.73^{\circ} \mathrm{N}$ and $116.33^{\circ} \mathrm{E}$ ) (Figure S1). The details about the observation site has been described in our previous work (Zhan et al., 2021). Briefly, the site is

90 a typical suburb site in Daxing District between the $5^{\text {th }}$ ring road and the $6^{\text {th }}$ ring road. The field

91 campaign was carried out during August $1^{\text {st }}-28^{\text {th }}$ in 2019 when photochemistry was the most

92 active while rainfall was rare in Beijing. 

chromatography-flame ionization detector (GC/FID) and a single photon ionization (SPI) TOFMS (SPI-MS 3000, Guangzhou Hexin Instrument Co., Ltd., China). A detailed description of

96 instrumentation can be found in previous publications (Zhan et al., 2021; Chen et al., 2020).

97 The SPI-MS was also deployed to detect halohydrocarbons. More details of this instrument and the parameter-setting have been described in previous studies(Zhang et al., 2019; Liu et al.,

99 2020a).. Briefly, a polydimethylsiloxane (PDMS; thickness of 0.002 int; Technical Products

100 Inc., USA) membrane was used to gathering VOCs and diffuse from the sample side to the detector side under high vacuum conditions. A vacuum ultraviolet (VUV) light generated by a

102 commercial D2 lamp (Hamamatsu, Japan) was utilized for ionization at $10.8 \mathrm{eV}$. For ion

103 detection, two microchannel plates (MCPs, Hamamatsu, Japan) assembled with a chevron-type

104 configuration are employed. This TOF-MS has an LOD varied from $50 \mathrm{ppt}$ to $1 \mathrm{ppb}$ with 1

105 minute of time resolution for most trace gases without any pre-concentration procedure. To

106 verify the data compatibility of the SPIMS and GC/FID, we compared the concentrations of

107 toluene measured using these two different instruments (Figure S2). The correlation coefficient

108 is 0.92 , indicating that the concentrations of NMHCs are comparable using these two

109 measurement techniques.

110 Oxygenated VOCs (OVOCs) were collected and analyzed using a high-performance

111 liquid chromatography (HPLC, Inertsil ODS-P $5 \mu \mathrm{m} 4.6 \times 250 \mathrm{~mm}$ column, GL Sciences) with

112 acetonitrile-water binary mobile phase(Ma et al., 2019). OVOCs were collected into 2,4-

113 dinitrophenylhydrazine (DNPH)-coated silica gel cartridges (Sep-Pak, Waters) by an automatic 
114 sampling device, with the sampling flow rate of $1.2 \mathrm{~L} \mathrm{~min}-1$ and the duration of $2 \mathrm{~h}$ for each

115 sample. To avoid possible contamination or desorption after sampling, cartridges were capped,

116 placed into tightly closed plastic bags and kept in a refrigerator before analysis. The sampled

117 cartridges were eluted by $5 \mathrm{~mL}$ acetonitrile and analyzed by HPLC as soon as possible after

118 they were shipped back to the laboratory. This system was calibrated through 8-gradient

119 standard solutions (TO11/IP-6A Aldehyde/Ketone-DNPH Mix, SUPELCO). The correlation

120 coefficients were all greater than 0.999 . The LOD for most OVOCs is about $10 \mathrm{ppt}$.

121 Trace gases, including $\mathrm{NO} x, \mathrm{SO}_{2}, \mathrm{CO}$, and $\mathrm{O}_{3}$, were measured using the corresponding

122 analyzer (Thermo Scientific, 42i, 43i, 48i, and 49i, respectively). The HONO concentration

123 was measured using a home-made long path absorption photometer (LOPAP) (Liu et al.,

124 2020c). The meteorological parameters, including temperature $(\mathrm{T})$, pressure $(\mathrm{P})$, relative

125 humidity (RH), wind speed, and wind direction, were measured using a weather station

126 (AWS310, Vaisala). The photolysis rate $\left(\mathrm{N}_{\mathrm{NO} 2}\right)$ was measured via a continuous measurement of

127 the actinic flux in the wavelength range of $285-375 \mathrm{~nm}$ using a $J_{\mathrm{NO} 2}$ filter-radiometer $\left(\mathrm{N}_{\mathrm{NO} 2}\right.$

128 radiometer, Metcon).

\subsection{Calculation of photochemical loss of VOCs.}

130 The photochemical loss of VOC was calculated using the ratio method (Wiedinmyer et

131 al., 2001; Yuan et al., 2013). The initial mixing ratio of a specific VOC was calculated using

132 the equations(Mckeen et al., 1996):

$$
\left[V O C_{i}\right]_{t}=\left[V O C_{i}\right]_{t 0} \times \exp \left(-k_{i} \times[O H] \times \Delta t\right)
$$

$$
\Delta t=\frac{1}{[O H] \times\left(k_{X}-k_{E}\right)} \times\left\{\ln \left(\frac{X_{0}}{E_{0}}\right)-\ln \left(\frac{X_{t}}{E_{t}}\right)\right\} \text { (2) }
$$


135 where $\left[V O C_{i}\right]_{t}$ and $\left[V O C_{i}\right]_{t o}$ are the observation concentration and the initial concentration of

$136 V O C_{i} ; k_{i}$ is the second-order reaction rates between the compound $i$ and $[\mathrm{OH}] ;[\mathrm{OH}]$ and $\Delta t$ are

137 the concentration of $\mathrm{OH}$ radical and photochemical aging time, respectively. $k_{X}$ and $k_{E}$ are rate

138 constant for the reaction between $\mathrm{OH}$ radicals and xylene $\left(7.00 \times 10^{-12} \mathrm{~cm}^{3}\right.$ molecule $\left.\mathrm{e}^{-1} \mathrm{~s}^{-1}\right)$ and

139 ethylbenzene $\left(1.87 \times 10^{-11} \mathrm{~cm}^{3}\right.$ molecule $\left.\mathrm{e}^{-1} \mathrm{~s}^{-1}\right)$ (Atkinson and Arey, 2003), respectively. $\left(X_{0} / E_{0}\right)$

140 is the ratio between the initial xylene and ethylbenzene mixing ratios, and $\left(X_{t} / E_{t}\right)$ is the ratio

141 between the observed xylene and ethylbenzene mixing ratios at time. In this study, we chose

142 the mean concentrations of xylene and ethylbenzene at 05:00-06:00 as the initial concentrations

143 (no photochemical loss) to calculate the photochemical loss of $\mathrm{OH}$ exposure. As can be seen

144 from Figure S3, the concentrations of xylene and ethylbenzene are well correlated, which

145 indicates that they are homologous emitted simultaneously. The calculated $\mathrm{OH}$ exposure $([\mathrm{OH}]$

$146 \times \Delta t$ ) was $4.3 \pm 1.9 \times 10^{6}$ molecule $\mathrm{cm}^{-3} \mathrm{~h}$. Accordingly, the mean photochemical ages were 1.7

$147 \pm 0.9 \mathrm{~h}$ using the mean daytime $(8: 00-17: 00 \mathrm{LT})$ OH concentrations $\left(4.3 \pm 3.1 \times 10^{6}\right.$ molecules

$148 \mathrm{~cm}^{-3}$ ) estimated using our previous method (Liu et al., 2020b; Liu et al., 2020c). This means

149 that the VOCs would undergo obvious degradation even in a short-range of transport in the

150 atmosphere.

151 It should be noted that the $k_{O H}$ of isoprene is $9.98 \times 10^{-11} \mathrm{~cm}^{3}$ molecule $\mathrm{s}^{-1}$ at $298.15 \mathrm{~K}$

152 (Atkinson and Arey, 2003), almost two orders than other VOCs. The ratio method assumes

153 constant emissions for VOCs. However, the emission of isoprene greatly depends on

154 temperature and solar irradiation intensity (Zhang et al., 2021b). Besides the photochemical

155 loss, additional correction of daytime isoprene concentrations was performed using the average 
shows a clear unimodal curve, and the volume concentration of isoprene is calculated based on the daily emission curve using Eq. (S1).

\subsection{Observation-based model simulation}

A box model based on the Master Chemical Mechanism (MCM3.3.1) and the Regional Atmospheric Chemical Mechanism (RACM2) were used in this study. The MCM3.3.1 was used to understand the instantaneous ozone formation process, and the RACM2 was used to depict the ozone isopleth due to the high computational efficiency (Sect. 2.4). Table S1 shows the model inputs. The model calculation is constrained with the measured meteorological parameters $\left(\mathrm{RH}, \mathrm{T}, \mathrm{P}\right.$, and $\left.J_{\mathrm{NO} 2}\right)$ and the concentrations of trace gases, including inorganic species (NO, $\mathrm{NO}_{2}, \mathrm{CO}, \mathrm{SO}_{2}$, and $\mathrm{HONO}$ ) and 61 organic species (NMHCs (46), OVOCs (8), and halohydrocarbons (7)). The model was validated using the observed and simulated $\mathrm{O}_{3}$ concentrations, which showed good consistency as shown in Figure. S5. The slope and correlation coefficient were 0.90 and 0.82 (Figure. S6), respectively, indicating the rationality of model simulation.

173 radical concentrations are used to calculate the ozone production rate.

$$
\mathrm{P}\left(\mathrm{O}_{3}\right)=k_{\mathrm{HO}_{2}+\mathrm{NO}}\left[\mathrm{HO}_{2}\right][\mathrm{NO}]+k_{\mathrm{RO}_{2}+\mathrm{NO}}\left[\mathrm{RO}_{2}\right][\mathrm{NO}]
$$

175 where $P\left(\mathrm{O}_{3}\right)$ is the ozone formation rate; $\left[\mathrm{HO}_{2}\right]$ and $\left[\mathrm{RO}_{2}\right]$ are the number concentrations of $176 \mathrm{HO}_{2}$ and $\mathrm{RO}_{2}$ radicals; $\mathrm{kHO}_{2+\mathrm{NO}}$ and $k_{\mathrm{RO} 2+\mathrm{NO}}$ are the second reaction rates between the $\mathrm{HO}_{2}$ and 

et al., 2019),

$$
k_{\mathrm{NO}_{2}+\mathrm{OH}}\left[\mathrm{NO}_{2}\right][\mathrm{OH}]
$$

where $L\left(\mathrm{O}_{3}\right)$ is the ozone chemical loss rate; $[\mathrm{HO}]$ is the number concentration of $H O$ radical; $\mathrm{kO}_{3+\mathrm{OH}}, \mathrm{kO}_{3+\mathrm{HO}}$, and $\mathrm{kO}_{\mathrm{O}+\text { alkenes }}$ are the second reaction rate between the $\mathrm{O}_{3}$ and $\mathrm{OH}, \mathrm{HO}_{2}$ and alkenes, respectively; and $\mathrm{kOO}_{2}+\mathrm{OH}$ is the second reaction rate between the $\mathrm{NO}_{2}$ and $\mathrm{OH}$. Finally, $F\left(O_{3}\right)$ is the net ozone formation rate by the difference between the $P\left(O_{3}\right)$ and $L\left(O_{3}\right)$ as expressed in Eq. (5),

$$
\mathrm{F}\left(\mathrm{O}_{3}\right)=\mathrm{P}\left(\mathrm{O}_{3}\right)-\mathrm{L}\left(\mathrm{O}_{3}\right)
$$

\subsection{Empirical Kinetic Modeling Approach}

The empirical kinetic modeling approach (EKMA) used in this work is a set of imaginary tests to reveal the dependence of photochemical oxidation products on the change in precursors. We set up $30 \times 30$ matrixes by reducing or increasing the measured VOCs and NOx concentrations to the model input. The resulting radical concentrations and ozone production rates are calculated correspondingly.

195 In this stage, the observed VOCs are grouped into different parcels according to the 196 classification of RACM2, and more details can be found in the previous publication (Tan et al.,

197 2017). The chemical model simulates the photochemical reactions with the parameters at a 
198 time interval of 5 minutes, which is enough for the $\mathrm{NO}, \mathrm{NO}_{2}, \mathrm{OH}, \mathrm{HO}_{2}$, and $\mathrm{RO}_{2}$ reaching steady state due to the typical relaxation time of the chemical system is 5-10 minutes in summer (Tan et al., 2018). The ozone production rate is calculated as described in Sect. 2.3.

\section{Results and discussion}

\subsection{Overview of diurnal variation of $\mathrm{O}_{3}, \mathrm{NO} x$, TVOC}

Figure 1 shows the average diurnal variation of $\mathrm{O}_{3}, \mathrm{NO} x$, and TVOCs (includes alkanes,

alkenes, OVOCs, and halohydrocarbons), driven by the emissions, photochemical reactions and the evolution of the mixing layer height (MLH). The ozone concentration during the observation period was $44.8 \pm 27.2 \mathrm{ppb}$ with a maximum of $119.1 \mathrm{ppb}$ as reported in our previous study (Zhan et al., 2021), which is generally comparable with the $\mathrm{O}_{3}$ concentrations during 2014-2018 (Ma et al., 2020). $\mathrm{O}_{3}$ followed a unimodal curve with a minimum (18.8 \pm 15.4 $\mathrm{ppb})$ at $07: 00$, then increased to the maximum $(69.6 \mathrm{ppb})$ at 15:00 as photochemical ozone formation. On the contrary, NOx was up to the maximum concentration $(39.7 \pm 14.2 \mathrm{ppb})$ at 07:00, and then decreased. After 07:00, the mixing ratio of NO went down all the time, while

212 the concentration of $\mathrm{NO}_{2}$ decreased at first, while started to grow at 14:00. The diurnal

213 variations of the observed TVOCs were generally consistent with $\mathrm{NO}_{2}$. The observed TVOCs

214 concentrations ranged from 2.2 to $23.2 \mathrm{ppb}$, with a mean value of $18.6 \pm 2.6 \mathrm{ppb}$. Compared to 215 the same period (45.4 $\pm 15.2 \mathrm{ppb}$ ) in August 2015 (Li et al., 2016a), the concentration of VOCs 216 in Beijing has been effectively reduced. However, the photochemical initial concentrations 217 (PICs) of TVOCs, which varied from 2.2 to $31.2 \mathrm{ppb}$ with a mean value of $22.4 \pm 3.8 \mathrm{ppb}$, 218 showed a different diurnal curve compared with the observed one. It slightly increased from 

and organic aerosol formation.

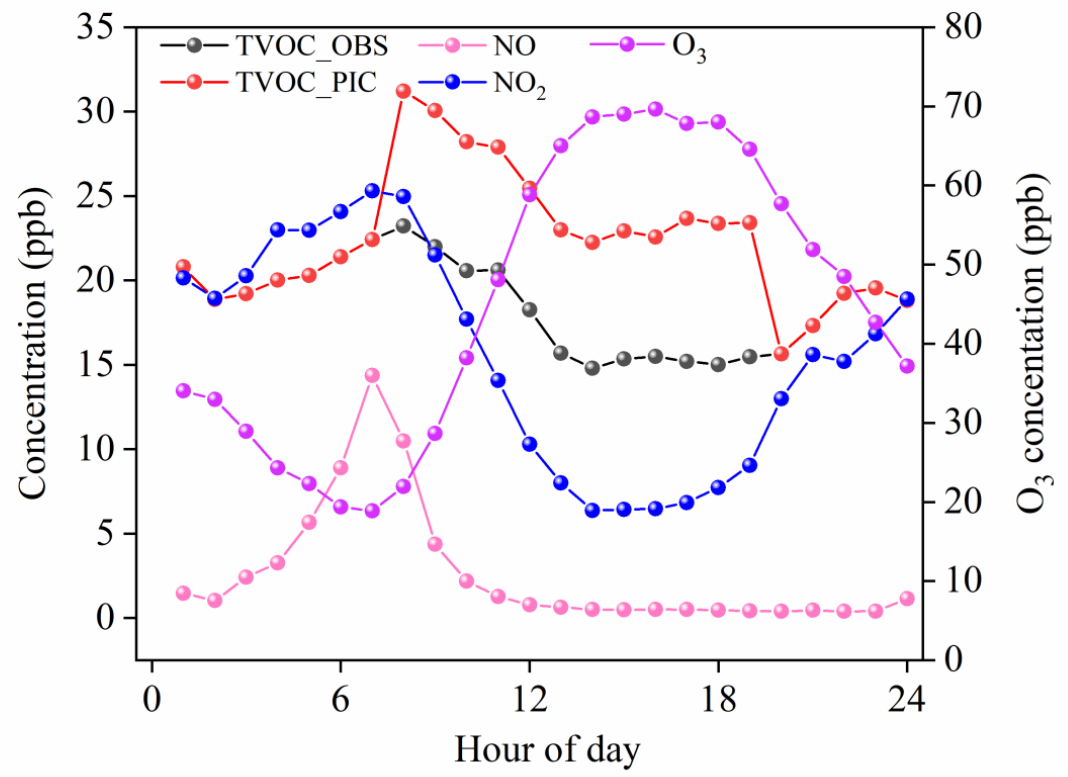

Figure. 1. Overview of diurnal variations of $\mathrm{O}_{3}, \mathrm{NO} x$, and TVOC

\subsection{Influence of photochemical loss of VOCs on $\mathrm{O}_{3}$ formation sensitivity regime}



noon, respectively, while the blue symbols are the corresponding values of PICs. Based on the

234 measured data, the $\mathrm{O}_{3}$ formation was in a VOCs-limited regime in the morning and a $\mathrm{NO} x$ -

235 limited regime at noon. The black arrow indicated a linearly decreasing trend of NOx and VOCs from 08:00 to 15:00 in the chemical coordinates system, and the ozone production shifted from VOC-limited to NOx-limited conditions from morning to noon, which was consistent with the

238 mean diurnal profiles (Figure. 1). This is similar to that reported in Wangdu (Tan et al., 2018).

239 As expected, the ozone production shifted from a VOC-limited regime (the observed VOCs)

240 to a transition one based on the PIC-VOCs in the morning. It further obviously moved to a

241 NOx-limited regime at noon after the photochemically consumed NOx and VOCs had been

242 accounted for (Figure. 2). These results denoted that the $\mathrm{O}_{3}$ formation mechanism might be 243 misdiagnosed, misleading the mitigation measures for $\mathrm{O}_{3}$ prevention if not considering the 244 consumed VOCs in the real atmospheric condition because the average photochemical aging

245 time was only $1.7 \pm 0.9 \mathrm{~h}$. 


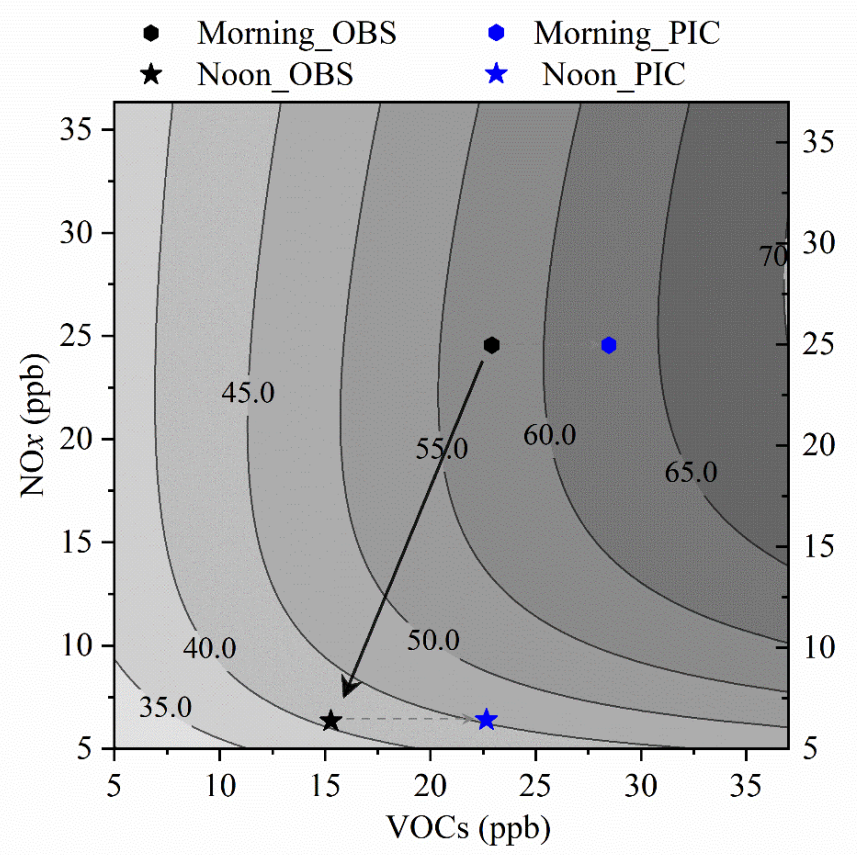

Figure 2. Isopleth diagram of the ozone concentration as functions of the concentration of NOx and VOCs derived from an empirical kinetic modeling approach. The pentagons and starts indicate the status in the morning and at noon, respectively. The black-filled and blue filled are the observed and corrected status, respectively.

\subsection{Contribution of VOC species to $\mathrm{O}_{3}$ production}

The time series of simulated $\mathrm{OH}, \mathrm{HO}_{2}$, and $\mathrm{RO}_{2}$ concentrations are used to calculate the $P\left(O_{3}\right)$ and $L\left(O_{3}\right)$. The diurnal averaged $P\left(O_{3}\right)$ and $L\left(O_{3}\right)$ are shown in Figure 3 . The ozone formation can be divided into $\mathrm{RO}_{2}+\mathrm{NO}$ and $\mathrm{HO}_{2}+\mathrm{NO}$ related processes (Sect. 2.3). According to VOC precursors, the peroxyl radical groups are divided into alkane-derived (ALKAP), alkene-derived (AlKEP), aromatic-derived (AROMP), isoprene-derived (ISOP), oxygenatedVOC-derived (OVOCP), and halohydrocarbon-derived (HALOP) $\mathrm{RO}_{2}$ and HO2P. The ozone destruction processes include the reaction between $\mathrm{O}_{3}$ and $\mathrm{HO} x(\mathrm{O} 3 \mathrm{D} 1)$, the reaction between $\mathrm{O} 1 \mathrm{D}$ and $\mathrm{H}_{2} \mathrm{O}(\mathrm{O} 3 \mathrm{D} 2)$, alkenes $(\mathrm{O} 3 \mathrm{D} 3)$, and the reaction between $\mathrm{NO}_{2}$ and $\mathrm{OH}(\mathrm{O} 3 \mathrm{D} 4)$. 

14:00 (or 13:00), with a diurnal maximum value of 16.1 (or 25.6) $\mathrm{ppb} \mathrm{h}^{-1}$ (Figure 3a and 3b), while the peaked destruction rate was 6.4 (or 8.6) $\mathrm{ppb} \mathrm{h}^{-1}$ at 15:00 (or 13:00) (Figure 3c and 3d). The average daytime $\mathrm{P}\left(\mathrm{O}_{3}\right)$ based on the initial concentrations of VOCs was $4.0 \pm 3.1 \mathrm{ppb}$ $\mathrm{h}^{-1}$ higher than that based on the measured concentrations (Figure 3b). At the same time, the $\mathrm{F}\left(\mathrm{O}_{3}\right)$ based on the initial concentrations of VOCs was also $3.0 \pm 2.1 \mathrm{ppb} \mathrm{h}^{-1}$ higher than the counterpart (Figure $\mathrm{S} 7$ ). Thus, the net $\mathrm{O}_{3}$ production can accumulatively be underestimated by

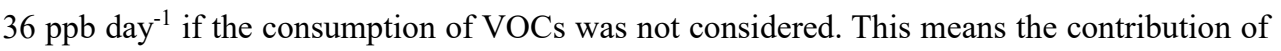
local formation of $\mathrm{O}_{3}$ should be underestimated using the directly measured VOCs concentrations. higher than the reported value (57.0\%) in Wangdu (Tan et al., 2018); whereas, the $\mathrm{RO}_{2}$ path contributed to the rest part, in which aromatics $(9.4 \%)$, alkenes $(8.4 \%)$, isoprene $(7.8 \%)$, alkanes (4.7\%), OVOCs (4.3\%) and halohydrocarbons $(0.6 \%)$ were the main contributors. As

274 for the PIC-VOCs, the dominant path of production of $\mathrm{O}_{3}(51.7 \%)$ was still the $\mathrm{HO}_{2}$ path, followed by the $\mathrm{RO}_{2}$ path related to alkenes (14.7\%), aromatics (12.8\%), and isoprene (11.7\%).

276 The relative contribution of the $\mathrm{RO}_{2}$ path to $\mathrm{P}\left(\mathrm{O}_{3}\right)$ increased by $13.4 \%$ compared with the 277 measured-VOCs, particularly alkenes derived $\mathrm{RO}_{2}$ increased $10.2 \%$. As shown in Figure 3c 278 and $3 \mathrm{~d}$, the destruction of total oxidants was dominated by the reaction between $\mathrm{O}_{3}$ and alkenes $279(\mathrm{O} 3 \mathrm{D} 3)$ in the morning. It gradually shifted to the reaction between $\mathrm{NO}_{2}$ and $\mathrm{OH}(\mathrm{O} 3 \mathrm{D} 4)$ from $28011: 00$ to $16: 00$, the photolysis of $\mathrm{O}_{3}$ followed by reaction with water (O3D2) from 12:00 to 

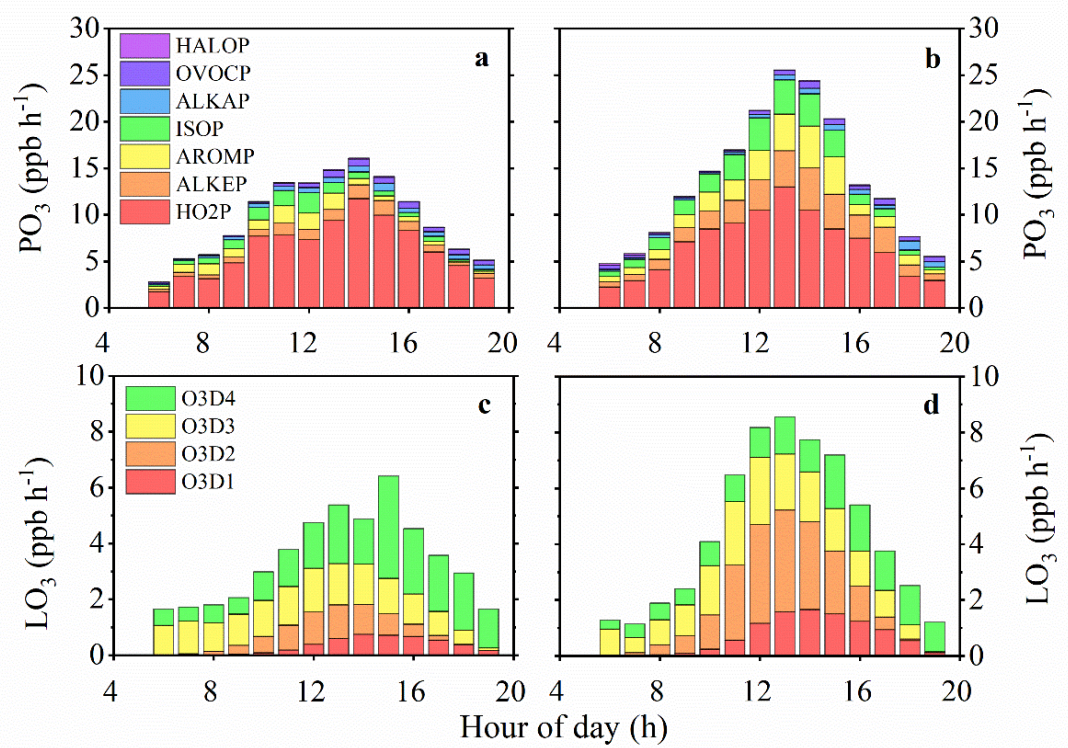
Hour of day (h)

289 Figure 3. Mean diurnal profile of the instantaneous ozone production and destruction rate 290 calculated from the MCM-OBM model (instantaneous ozone rate derived from observed VOCs 291 in a and c, and from PIC-VOCs in b and d). The upper panel presents the speciation ozone 292 formation rate. The lower panel presents the speciation ozone destruction rate.

The budget of $\mathrm{OH}-\mathrm{HO}_{2}-\mathrm{RO}_{2}$ radicals was further analyzed to understand the photochemical $\mathrm{O}_{3}$ formation process. All radical cycles are divided into four groups (source, sink, propagation, and equilibrium between radical and reservoir species) based on the different 
radical reaction processes (Tan et al., 2019). The comparison of radical budget derived from the observed and PIC-VOCs is shown in Figure 4. The values of different radical paths based on observed VOCs are in the range of radical budget analysis reported in Beijing, Shanghai,

299 and Guangzhou(Tan et al., 2019). The average formation rates (the numbers in Figure 4) of

300 these four processes $\left(\mathrm{OH}, \mathrm{HO}_{2}, \mathrm{RCO}_{3}\right.$, and $\left.\mathrm{RO}_{2}\right)$ derived from PIC-VOCs were higher than

301 that from the observed VOCs. In particular, the reaction between $\mathrm{NO}$ and $\mathrm{RO}_{2}$ and $\mathrm{HO}_{2}$

302 increased by 1.6 and $1.3 \mathrm{ppb} \mathrm{h}^{-1}$, respectively, which was equal to average $\mathrm{F}\left(\mathrm{O}_{3}\right)$ in the process

303 analysis above. The contribution for the reaction between $\mathrm{O}_{3}$ and alkenes to $\mathrm{HO}$ and $\mathrm{HO}_{2}$

304 radical increased $14 \%$ and $6 \%$, respectively. As for the radical sink, radical propagation, and

305 equilibrium, they were consistent with the radical source. Furthermore, the $\mathrm{O}_{3}$ formation from

306 the $\mathrm{RO}_{2}$ path based on the radical budget analysis increased $4.1 \%$ from $39.5 \%$ (observed-VOCs)

307 to $43.6 \%$ (PIC-VOCs). These results denote that the $\mathrm{O}_{3}$ formation process between the

308 observed and initial VOCs showed no significant difference, while the formation rate should

309 be underestimated if the consumed VOCs was not considered. 
Figure 4. Comparison of the $\mathrm{OH}-\mathrm{HO}_{2}-\mathrm{RO}_{2}$ radical budget derived from the observed and PICVOCs under the daytime conditions (07:00 to 19:00 LT). The green, black, red and yellow boxes denote the sources of radicals, radical sink, radical propagation, and the racial equilibrium, respectively. The numbers outside and inside the brackets in the boxes are the average formation rates $\left(\mathrm{ppb} \mathrm{h}^{-1}\right)$ from the observed and PIC-VOCs.

\subsection{In-situ $\mathrm{O}_{3}$ formation process}

Besides chemical processes, which can be simulated using the OBM-MCM model, the transport processes includes horizontal, vertical transportation and dry deposition processes (Tan et al., 2019) also have important influence on the $\mathrm{O}_{3}$ concentration. Thus, the change of instantaneous ozone concentration can reflect the combination effect between the photochemical and the physical transport processes (Tan et al., 2019) . It can be expressed as,

$$
\frac{d O_{x}}{d t}=F\left(O_{3}\right)+R\left(O_{3}\right)(6)
$$

where $d O x / d t$ is the $\mathrm{O}_{3}$ concentration change rate based on the measured data $\left(\mathrm{ppb} \mathrm{h}^{-1}\right) ; F\left(O_{3}\right)$ 


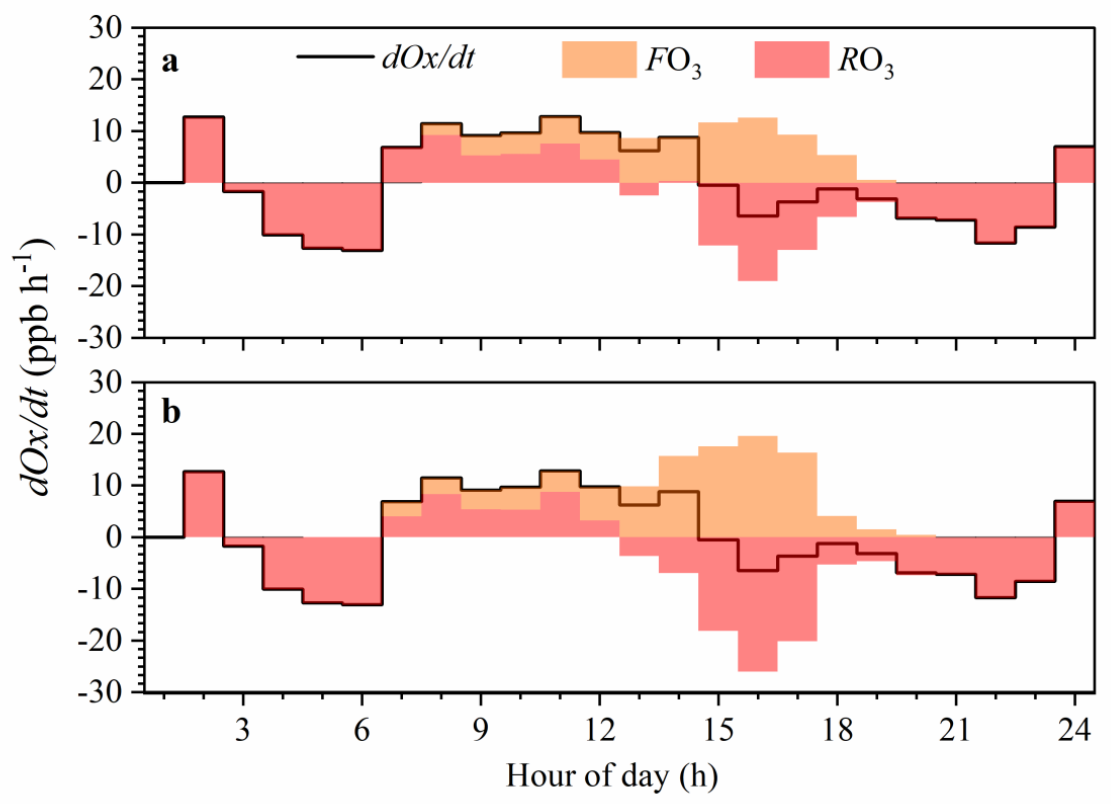

Fig. 5. The variation of $\mathrm{O} x$ concentration and formation rate on $\mathrm{O}_{3}$ pollution episode $\left(1^{\text {st }} \mathrm{Aug}\right)$. ( $a$ and $b$ present the local ozone formation process of the measured and PIC-VOCs, respectively.)

Here shows the $\mathrm{O}_{3}$ budget analysis occurred on a $\mathrm{O}_{3}$ pollution episode $\left(1^{\text {st }} \mathrm{Aug}\right)$. Figure 5 shows the simulated local ozone formation process based on the measured and PIC-VOCs. The hourly variation of $\mathrm{O}_{3}$ concentrations from 19:00 to 6:00 in the next day was dominated by the regional transportation without $\mathrm{O}_{3}$ formation, while the local photochemical $\mathrm{O}_{3}$ formation could explain all or a part of the $\mathrm{O}_{3}$ concentration change during the time window from 07:00 to 19:00. The $\mathrm{d}\left(\mathrm{O}_{3}\right) / \mathrm{dt}$ shows an increase from 07:00 to 15:00 LT. However, the $\mathrm{d}\left(\mathrm{O}_{3}\right) / \mathrm{dt}$ sharply changed to negative values at 16:00, which was consistent with the diurnal of $\mathrm{O}_{3}$ (the $\mathrm{O}_{3}$ peaks 
at 15:00) in Figure 1.

The average daytime $\mathrm{F}\left(\mathrm{O}_{3}\right)$ based on the observed and photochemical initial concentration was $6.4 \pm 4.0$ and $8.9 \pm 6.7 \mathrm{ppb} \mathrm{h}^{-1}$, respectively. The photochemical $\mathrm{O}_{3}$ formation under both conditions started at 07:00 and reached the maximum value of 12.6 and $19.6 \mathrm{ppb} \mathrm{h}^{-1}$ at 15:00, respectively. The maximum daily value of $\mathrm{P}\left(\mathrm{O}_{3}\right)$ is higher than the urban of Japan, America, and England (Whalley et al., 2018; Ren et al., 2006; Griffith et al., 2016; Kanaya et al., 2009),

344 lower than the suburb in Guangzhou (Lu et al., 2012), the urban and suburb of Beijing (Lu et al., 2013). Before 12:00, the $\mathrm{O}_{3}$ formation rate based on the PIC-VOCs was slightly higher than that based on the measured ones, while both of them were within the range of $2.0 \sim 6.5 \mathrm{ppb} \mathrm{h}^{-1}$. From 12:00 to 17:00, the $\mathrm{O}_{3}$ formation rate based on the PIC-VOCs and the observed concentration of VOCs greatly increased due to the active photochemistry.

As shown in Figure 5, the increased $\mathrm{O}_{3}$ concentration was larger than the local $\mathrm{O}_{3}$ photochemical production from 07:00 to 14:00 $\left(\mathrm{R}\left(\mathrm{O}_{3}\right)\right.$ was positive). This implied an additional $\mathrm{O}_{3}$ source from the outside regions. However, the $\mathrm{R}\left(\mathrm{O}_{3}\right)$ was negative in the afternoon, which meant that the local $\mathrm{O}_{3}$ formation at the measure site contributed to not only the changes of insitu $\mathrm{O}_{3}$ concentration but also the $\mathrm{O}_{3}$ source of the downwind regions. This is more obviously observed in Figure 4B in the condition of the PIC-VOCs. These results illustrated that local $\mathrm{O}_{3}$ photochemistry plays a crucial role in both the local and regional $\mathrm{O}_{3}$ concentrations, that will be underestimated if the consumed VOCs with high reactivities are ignored.

\section{Conclusions}

In this study, we present the local $\mathrm{O}_{3}$ formation process in August 2019 in Beijing based 
on the concentrations of the observed and PIC-VOCs. The mean diurnal profile of $\mathrm{O}_{3}$ was unimodal with peaks at 15:00, while NOx and observed TVOCs showed an opposite diurnal curve, and the PICs of TVOCs showed a different diurnal curve compared with the observed one with slight increase from 14:00 to 17:00. The EKMA curve indicated that the instantaneous $\mathrm{O}_{3}$ production was dependent on the real-time concentrations of NOx and VOCs, i.e., VOCslimited regime in the morning and $\mathrm{NO} x$-limited regime at noon. The sensitivity regime of $\mathrm{O}_{3}$ formation could be misdiagnosed without considering the consumed VOCs, such as a VOClimited regime (observed) shifting to a transition regime (PIC-VOCs) in the morning. The mean $\mathrm{F}\left(\mathrm{O}_{3}\right)$ based on PIC- VOCs was $3.0 \mathrm{ppb} \mathrm{h}^{-1}$ higher than that based on the measured VOCs, indicating that the underestimation of local photochemistry to local $\mathrm{O}_{3}$ concentration could reached $36 \mathrm{ppb}$ day $^{-1}$ if the consumed VOCs were not accounted for. The radical budget analysis illustrated that the $\mathrm{O}_{3}$ formation processes between the observed and photochemical initial VOCs showed no significant difference, but the former one underestimated the $\mathrm{O}_{3}$ production rate obviously. Finally, the results of in-situ $\mathrm{O}_{3}$ formation process denoted that local $\mathrm{O}_{3}$ photochemical formation plays a key role in both local and regional $\mathrm{O}_{3}$ concentrations. In a conclusion, our results suggest that the PIC-VOCs should be more suitable to diagnose the $\mathrm{O}_{3}$ formation sensitivity than the observed VOCs concentrations. 
379 Author contributions: Wei Ma: Methodology, Data curation, Writing-original draft; Zemin

Feng: Methodology, Investigation, Data curation, Writing-original draft; Junlei Zhan:

Methodology, Investigation, Data curation; Yongchun Liu: Conceptualization, Investigation,

Data curation, Writing-review \& editing, Supervision, Funding Acquisition; Pengfei Liu: curation. Yafei Wang: Methodology, Investigation, Resources, Data curation; Hong He: Supervision.

Competing interests: The authors declare that they have no substantive conflicts of interest.

Data availability: Data are available upon request to Yongchun Liu (liuyc@buct.edu.cn)

Acknowledgements: This research was financially supported by the National Natural Science 


\section{Reference}

401 Atkinson, R. and Arey, J.: Atmospheric degradation of volatile organic compounds, Chemical Reviews, 103, 4605-

402 4638, https://doi.org/10.1021/cr0206420, 2003.

403 Chen, T., Liu, J., Liu, Y., and Ma, Q. G., Yanli; Zhong,Cheng; Jiang,Haotian; Chu,Biwu; Zhang,Peng; Ma,Jinzhu;

404 Liu,Pengfei; Wang,Yafei; Mu,Yujing; He,Hong: Chemical characterization of submicron aerosol in summertime

405 Beijing: A case study in southern suburbs in 2018, Chemosphere, 247,

406 https://doi.org/10.1016/j.chemosphere.2020.125918, 2020.

407 Cohen, A. J., Brauer, M., Burnett, R., and Anderson, H. R. F., Joseph; Estep,Kara; Balakrishnan,Kalpana; 408 Brunekreef,Bert; Dandona,Lalit; Dandona,Rakhi; Feigin,Valery; Freedman,Greg; Hubbell,Bryan; Jobling,Amelia; 409 Kan,Haidong; Knibbs,Luke; Liu,Yang; Martin,Randall; Morawska,Lidia; Pope,C. Arden, III; Shin,Hwashin; 410 Straif,Kurt; Shaddick, Gavin; Thomas,Matthew; van Dingenen,Rita; van Donkelaar,Aaron; Vos,Theo; 411 Murray,Christopher J. L; Forouzanfar,Mohammad H.: Estimates and 25-year trends of the global burden of disease 412 attributable to ambient air pollution: an analysis of data from the Global Burden of Diseases Study 2015, Lancet, 413 389, 1907-1918, https://doi.org/10.1016/s0140-6736(17)30505-6, 2017.

414 Dang, R. and Liao, h.: Radiative Forcing and Health Impact of Aerosols and Ozone in China as the Consequence 415 of Clean Air Actions over 2012-2017, J Geophysical Research Letters, 46, 416 https://doi.org/10.1029/2019GL084605, 2019.

417 Feng, Z., De Marco, A., Anav, A., Gualtieri, M., Sicard, P., Tian, H., Fornasier, F., Tao, F., Guo, A., and Paoletti, 418 E.: Economic losses due to ozone impacts on human health, forest productivity and crop yield across China, 419 Environment International, 131, https://doi.org/10.1016/j.envint.2019.104966, 2019.

420 Gao, J., Zhang, J., Li, H., Li, L., and Xu, L. Z., Yujie; Wang,Zhanshan; Wang,Xuezhong; Zhang,Weiqi; 421 Chen,Yizhen; Cheng,Xi; Zhang,Hao; Peng,Liang; Chai,Fahe; Wei,Yongjie: Comparative study of volatile organic 422 compounds in ambient air using observed mixing ratios and initial mixing ratios taking chemical loss into account 423 - A case study in a typical urban area in Beijing, Science of the Total Environment, 628-629, 791-804, 424 https://doi.org/10.1016/j.scitotenv.2018.01.175, 2018.

425 Gao, Y., Li, M., Wan, X., Zhao, X., Wu, Y., Liu, X., and Li, X.: Important contributions of alkenes and aromatics 426 to VOCs emissions, chemistry and secondary pollutants formation at an industrial site of central eastern China, 427 Atmospheric Environment, 244, https://doi.org/10.1016/j.atmosenv.2020.117927, 2021.

428 Griffith, S. M., Hansen, R. F., Dusanter, S., Michoud, V., Gilman, J. B., Kuster, W. C., Veres, P. R., Graus, M., de 429 Gouw, J. A., Roberts, J., Young, C., Washenfelder, R., Brown, S. S., Thalman, R., Waxman, E., Volkamer, R., Tsai, 430 C., Stutz, J., Flynn, J. H., Grossberg, N., Lefer, B., Alvarez, S. L., Rappenglueck, B., Mielke, L. H., Osthoff, H. 431 D., and Stevens, P. S.: Measurements of hydroxyl and hydroperoxy radicals during CalNex-LA: Model 432 comparisons and radical budgets, Journal of Geophysical Research-Atmospheres, 121, 4211-4232, 433 https://doi.org/10.1002/2015jd024358, 2016.

434 Han, D., Wang, Z., Cheng, J., Wang, Q., Chen, X., and Wang, H.: Volatile organic compounds (VOCs) during 435 non-haze and haze days in Shanghai: characterization and secondary organic aerosol (SOA) formation, 436 Environmental Science and Pollution Research, 24, 18619-18629, https://doi.org/10.1007/s11356-017-9433-3, 4372017.

438 He, Z., Wang, X., Ling, Z., Zhao, J., Guo, H., Shao, M., and Wang, Z.: Contributions of different anthropogenic 439 volatile organic compound sources to ozone formation at a receptor site in the Pearl River Delta region and its 440 policy implications, Atmospheric Chemistry and Physics, 19, 8801-8816, https://doi.org/10.5194/acp-19-8801- 
441

$\underline{2019}, 2019$.

Kanaya, Y., Pochanart, P., Liu, Y. L., J;, Tanimoto, H., Kato, S., Suthawaree, J., Inomata, S., Taketani, F., Okuzawa, K., Kawamura, K., Akimoto, H., and Wang, Z. F.: Rates and regimes of photochemical ozone production over Central East China in June 2006: a box model analysis using comprehensive measurements of ozone precursors, Atmospheric Chemistry and Physics, 9, 7711-7723, https://doi.org/10.5194/acp-9-7711-2009, 2009.

Li, J., Wu, R., Li, Y., Hao, Y., and Xie, S. Z., Liming;: Effects of rigorous emission controls on reducing ambient volatile organic compounds in Beijing, China, Science of the Total Environment, 557, 531-541, https://doi.org/10.1016/j.scitotenv.2016.03.140, 2016a.

Li, J., Yang, W., Wang, Z., Chen, H., Hu, B., Li, J., Sun, Y., Fu, P., and Zhang, Y.: Modeling study of surface ozone source-receptor relationships in East Asia, Atmospheric Research, 167, 77-88, https://doi.org/10.1016/j.atmosres.2015.07.010, 2016b.

Li, L., An, J. Y., Shi, Y. Y., and Zhou, M. Y., R. S; Huang, C; Wang, H. L; Lou, S. R; Wang, Q; Lu, Q; Wu, J.: Source apportionment of surface ozone in the Yangtze River Delta, China in the summer of 2013, Atmospheric Environment, 144, 194-207, https://doi.org/10.1016/j.atmosenv.2016.08.076, 2016c. Li, M., Zhang, Q., Zheng, B., Tong, D., Lei, Y., Liu, F., Hong, C., Kang, S., Yan, L., Zhang, Y., Bo, Y. S., Hang;, Cheng, Y., and He, K.: Persistent growth of anthropogenic non-methane volatile organic compound (NMVOC) emissions in China during 1990-2017: drivers, speciation and ozone formation potential, Atmospheric Chemistry and Physics, 19, 8897-8913, https://doi.org/10.5194/acp-19-8897-2019, 2019.

Ling, Z. H. and Guo, H.: Contribution of VOC sources to photochemical ozone formation and its control policy implication in Hong Kong, Environmental Science \& Policy, 38, 180-191, https://doi.org/10.1016/j.envsci.2013.12.004, 2014.

Liu, Y., Yan, C., Feng, Z., Zheng, F., and Kulmala, M.: Continuous and comprehensive atmospheric observations in Beijing: a station to understand the complex urban atmospheric environment, Big Earth Data, 4, 295-321, https://doi.org/10.1080/20964471.2020.1798707, 2020a.

Liu, Y., Ni, S., Jiang, T., Xing, S., Zhang, Y., Bao, X., Feng, Z., Fan, X., Zhang, L., and Feng, H.: Influence of Chinese New Year overlapping COVID-19 lockdown on HONO sources in Shijiazhuang, Science of the Total Environment, 745, https://doi.org/10.1016/j.scitotenv.2020.141025, 2020b.

Liu, Y., Zhang, Y., Lian, C., Yan, C., Feng, Z., Zheng, F., Fan, X., Chen, Y., Wang, W., Chu, B., Wang, Y., Cai, J., Du, W., Daellenbach, K. R., Kangasluoma, J., Bianchi, F., Kujansuu, J., Petaja, T., Wang, X., Hu, B., Wang, Y., Ge, M., He, H., and Kulmala, M.: The promotion effect of nitrous acid on aerosol formation in wintertime in Beijing: the possible contribution of traffic-related emissions, Atmospheric Chemistry and Physics, 20, 1302313040, https://doi.org/10.5194/acp-20-13023-2020, 2020c.

Lu, K. D., F. Rohrer; F. Holland, H. F., B. Bohn,T. Brauers,C. C. Chang,R. Haseler ,M. Hu,K. Kita, and , Y. K., X. Li,S. R. Lou,S. Nehr,M. Shao,L. M. Zeng,A. Wahner,Y. H. Zhang,and A. Hofzumahaus: Observation and modelling of $\mathrm{OH}$ and $\mathrm{HO} 2$ concentrations in the Pearl River Delta 2006: a missing OH source in a VOC rich atmosphere, Atmospheric Chemistry and Physics, 12, 1541-1569, https://doi.org/10.5194/acp-12-1541-2012, 2012.

Lu, K. D., Hofzumahaus, A., Holland, F., Bohn, B., Brauers, T., Fuchs, H., Hu, M., Haeseler, R., Kita, K., Kondo, Y., Li, X., Lou, S. R., Oebel, A., Shao, M., Zeng, L. M., Wahner, A., Zhu, T., Zhang, Y. H., and Rohrer, F.: Missing $\mathrm{OH}$ source in a suburban environment near Beijing: observed and modelled $\mathrm{OH}$ and $\mathrm{HO} 2$ concentrations in summer 2006, Atmospheric Chemistry and Physics, 13, 1057-1080, https://doi.org/10.5194/acp-13-1057-2013, 2013. 
Lu, X., Chen, N., Wang, Y., Cao, W., Zhu, B., Yao, T., Fung, J. C. H., and Lau, A. K. H.: Radical budget and ozone chemistry during autumn in the atmosphere of an urban site in central China, Journal of Geophysical ResearchAtmospheres, 122, 3672-3685, https://doi.org/10.1002/2016jd025676, 2017. Ma, j. K., Jyoti;, Li, V. O. K., and Lam, J. C. K.: Effects of China's current Air Pollution Prevention and Control Action Plan on air pollution patterns, health risks and mortalities in Beijing 2014-2018, Chemosphere, 260, https://doi.org/10.1016/j.chemosphere.2020.127572, 2020.

Ma, Z., Liu, C., Zhang, C., Liu, P., Ye, C., Xue, C., Zhao, D., Sun, J., Du, Y., Chai, F., and Mu, Y.: The levels, sources and reactivity of volatile organic compounds in a typical urban area of Northeast China, Journal of Environmental Sciences, 79, 121-134, 10.1016/j.jes.2018.11.015, 2019.

Mckeen, S. A., Liu, S. C., Hsie, E. Y., Lin, X., Bradshaw, J. D., Smyth, S., Gregory, G. L., and Blake, D. R.: Hydrocarbon ratios during PEM-WEST A: A model perspective, Journal of Geophysical Research: Atmospheres, 101, https://doi.org/10.1029/95JD02733, 1996.

Monks, P. S.: Gas-Phase Radical Chemistry in the Troposphere, Chemical Society Reviews, 34, 376-395, https://doi.org/10.1039/B307982C, 2005.

Pan, X., Kanaya, Y., Tanimoto, H., Inomata, S., Wang, Z., Kudo, S., and Uno, I.: Examining the major contributors of ozone pollution in a rural area of the Yangtze River Delta region during harvest season, Atmospheric Chemistry and Physics, 15, 6101-6111, https://doi.org/10.5194/acp-15-6101-2015, 2015.

Ren, X., Brune, W. H., Mao, J., Mitchell, M. J., Lesher, R. L., Simpas, J. B., Metcalf, A. R., Schwab, J. J., Cai, C., Li, Y., Demerjian, K. L., Felton, H. D., Boynton, G., Adams, A., Perry, J., He, Y., Zhou, X., and Hou, J.: Behavior of $\mathrm{OH}$ and $\mathrm{HO} 2$ in the winter atmosphere in New York city, Atmospheric Environment, 40, S252-S263, https://doi.org/10.1016/j.atmosenv.2005.11.073, 2006.

Seinfeld and JohnH: Atmospheric chemistry and physics : from air pollution to climate change / 2nd ed, Atmospheric chemistry and physics : from air pollution to climate change / 2nd ed2006.

Shao, M., Wang, B., Lu, S., Yuan, B., and Wang, M.: Effects of Beijing Olympics Control Measures on Reducing Reactive Hydrocarbon Species, Environmental Science \& Technology, 45, 514-519, https://doi.org/10.1021/es102357t, 2011.

Tan, Z., Fuchs, H., Lu, K., and Hofzumahaus, A. B., Birger; Broch,Sebastian; Dong,Huabin; Gomm,Sebastian; Haeseler,Rolf; He,Lingyan; Holland,Frank; Li,Xin; Liu,Ying; Lu,Sihua; Rohrer,Franz; Shao,Min; Wang,Baolin; Wang,Ming; Wu,Yusheng; Zeng,Limin; Zhang,Yinsong; Wahner,Andreas; Zhang,Yuanhang;: Radical chemistry at a rural site (Wangdu) in the North China Plain: observation and model calculations of OH,HO2 and RO2 radicals, Atmospheric Chemistry and Physics, 17, 663-690, https://doi.org/10.5194/acp-17-663-2017, 2017.

Tan, Z., Lu, K., Jiang, M., Rong, S., and Zhang, Y.: Daytime atmospheric oxidation capacity in four Chinese megacities during the photochemically polluted season: A case study based on box model simulation, Atmospheric Chemistry Physics, 19, 3493-3513, https://doi.org/10.5194/acp-19-3493-2019, 2019.

Tan, Z., Lu, K., Jiang, M., Su, R., Dong, H., Zeng, L., Xie, S., Tan, Q., and Zhang, Y.: Exploring ozone pollution in Chengdu, southwestern China: A case study from radical chemistry to O-3-VOC-NOx sensitivity, Science of the Total Environment, 636, 775-786, https://doi.org/10.1016/j.scitotenv.2018.04.286, 2018.

Wang, T., Xue, L., Brimblecombe, P., Lam, Y. F., Li, L., and Zhang, L.: Ozone pollution in China: A review of concentrations, meteorological influences, chemical precursors, and effects, Science of the Total Environment, 575, 1582-1596, https://doi.org/10.1016/j.scitotenv.2016.10.081, 2017.

Whalley, L. K., Stone, D., Dunmore, R., Hamilton, J., Hopkins, J. R., Lee, J. D., Lewis, A. C., Williams, P., Kleffmann, J., Laufs, S., Woodward-Massey, R., and Heard, D. E.: Understanding in situ ozone production in the 

(ClearfLo), Atmospheric Chemistry and Physics, 18, 2547-2571, https://doi.org/10.5194/acp-18-2547-2018, 2018. Wiedinmyer, C., Friedfeld, S., Baugh, W., Greenberg, J., Guenther, A., Fraser, M., and Allen, D.: Measurement and analysis of atmospheric concentrations of isoprene and its reaction products in central Texas, Atmospheric Environment, 35, 1001-1013, https://doi.org/10.1016/S1352-2310(00)00406-4, 2001.

530 Xie, Y., Dai, H., Zhang, Y., Wu, Y., Hanaoka, T., and Masui, T.: Comparison of health and economic impacts of PM2.5 and ozone pollution in China, Environment International, 130, https://doi.org/10.1016/j.envint.2019.05.075, 2019.

Xue, L. K., Wang, T., Gao, J., Ding, A. J., Zhou, X. H., Blake, D. R., Wang, X. F., Saunders, S. M., Fan, S. J., Zuo, 534 H. C., Zhang, Q. Z., and Wang, W. X.: Ground-level ozone in four Chinese cities: precursors, regional transport 535 and heterogeneous processes, Atmospheric Chemistry and Physics, 14, 13175-13188, https://doi.org/10.5194/acp$536 \quad 14-13175-2014,2014$.

537 Yang, Y., Shao, M., Kessel, S., Li, Y. L., Keding;, Lu, S. W., Jonathan;, Zhang, Y., Zeng, L., Noelscher, A. C., Wu, 538 Y., Wang, X., and Zheng, J.: How the $\mathrm{OH}$ reactivity affects the ozone production efficiency: case studies in Beijing 539 and Heshan, China, Atmospheric Chemistry and Physics, 17, 7127-7142, https://doi.org/10.5194/acp-17-7127$540 \underline{2017}, 2017$.

541 Yuan, B., Hu, W. W., Shao, M., Wang, M., Chen, W. T., Lu, S. H., Zeng, L. M., and Hu, M.: VOC emissions, 542 evolutions and contributions to SOA formation at a receptor site in eastern China, Atmospheric Chemistry and 543 Physics, 13, 8815-8832, https://doi.org/10.5194/acp-13-8815-2013, 2013.

544 Zhan, J., Feng, Z., Liu, P., He, X., He, Z., Chen, T., Wang, Y., He, H., Mu, Y., and Liu, Y.: Ozone and SOA 545 formation potential based on photochemical loss of VOCs during the Beijing summer, Environmental Pollution, 546 285, https://doi.org/10.1016/j.envpol.2021.117444, 2021.

547 Zhang, K., Li, L., Huang, L., Wang, Y., Huo, J., Duan, Y., Wang, Y., and Fu, Q.: The impact of volatile organic 548 compounds on ozone formation in the suburban area of Shanghai, Atmospheric Environment, 232, 549 https://doi.org/10.1016/j.atmosenv.2020.117511, 2020.

550 Zhang, K., Huang, L., Li, Q., Huo, J., Duan, Y., Wang, Y., Yaluk, E., Wang, Y., Fu, Q., and Li, L.: Explicit modeling of isoprene chemical processing in polluted air masses in suburban areas of the Yangtze River Delta region: radical cycling and formation of ozone and formaldehyde, Atmospheric Chemistry and Physics, 21, 5905-5917, https://doi.org/10.5194/acp-21-5905-2021, 2021a.

554 Zhang, M., Gao, W., Yan, J., Wu, Y., Marandino, C. A., Park, K., Chen, L., Lin, Q., Tan, G., and Pan, M.: An 555 integrated sampler for shipboard underway measurement of dimethyl sulfide in surface seawater and air, 556 Atmospheric Environment, 209, 86-91, https://doi.org/10.1016/j.atmosenv.2019.04.022, 2019.

557 Zhang, Q., Li, L., Zhao, W., Wang, X., Jiang, L., Liu, B., Li, X., and Lu, H.: Emission characteristics of VOCs 558 from forests and its impact on regional air quality in Beijing, China Environmental Science, 41, 622-632, 559 https://doi.org/10.19674/j.cnki.issn1000-6923.2021.0072, 2021b.

560 Zhang, S., Li, D., Ge, S., Liu, S., Wu, C., Wang, Y., Chen, Y., Lv, S., Wang, F., Meng, J., and Wang, G.: Rapid 561 sulfate formation from synergetic oxidation of $\mathrm{SO} 2$ by $\mathrm{O} 3$ and $\mathrm{NO} 2$ under ammonia-rich conditions: Implications 562 for the explosive growth of atmospheric PM2.5 during haze events in China, Science of The Total Environment, $563772,10.1016 /$ j.scitotenv.2020.144897, 2021c. 